\title{
Trade in-Game Meat in Jagaraga Village, West Lampung from an Islamic Law Perspective
}

\author{
Sandriansyah $^{1}$, Maratul Qiftiyah ${ }^{2}$ \\ 1,2 Pascasarjana Universitas Islam Negeri Sunan Kalijaga Yogyakarta - Indonesia \\ e-mail: sandriansyahgejora@gmail.com, maratulqiftiyah@gmail.com
}

\begin{abstract}
This study aims to see the legal status of the game meat trade in Islamic law. This type of research is field research, using observation and interviews with huntersand players who buy and sell game meat Trading in-game meat must not violate religious and state regulations. This paper finds that hunting and trading animal meat in the field against protected animals is prohibited by Islamic law. Hunting needs to be supervised by those who care so that the ecosystem is well preserved.
\end{abstract}

Keywords: Islamic law; buying and selling; game meat

\section{]}

Penelitian ini bertujuan untuk melihat status hukum perdagangan daging buruan dalam hukum Islam. Jenis penelitian ini adalah penelitian lapangan, dengan menggunakan metode observasi dan wawancara dengan pemburu dan pemain yang melakukan jual beli daging buruan. Perdagangan daging hewan buruan tidak boleh melanggar peraturan agama dan negara. Tulisan ini menemukan bahwa perburuan dan perdagangan daging hewan yang dilakukan di lapangan terhadap hewan yang dilindungi dilarang oleh hukum Islam. Perburuan perlu diawasi oleh yang peduli, agar ekosistemnya tetap terjaga dengan baik.

Kata Kunci: hukum Islam; jual beli; daging hewan buruan 


\section{Introduction}

Jagaraga Village is located in Sukau District, West Lampung Regency. The majority of the people there are farmers. The location of the settlement is at the foot of Mount Seminung. Apart from their daily activities as farmers, some residents go hunting, which has become a habit for them every week. Hunting activities are carried out on Fridays, and hunting activities are carried out in groups with the necessary hunting equipment. The animals targeted by hunters are mostly pigs, which are considered pests there, but they also hunt protected animals such as deer, deer, pangolins, etc. Hunts obtained from hunting activities are hunting animals, live or dead or their parts.

In Islam, buying and selling are legal and justified by religion, as long as it fulfills the requirements and harmony. Thus this law has been approved by the experts of ijmā'. It is stated in the Koran that selling is lawful, while trading, which contains ambiguity, is prohibited. ${ }^{1}$ In line with that in buying and selling, some conditions must be met, while the requirements required in 'aqd (contract) of buying and selling consist of al-áqidayn (two people who make the contract), mahal al-'aqd (contract place), mawdü' al-'aqd (purpose of the contract), and pillars of 'aqd. Whereas seen from muamalah fiqh, buying and selling as part of muamalah has a clear legal basis, both from the Qur'an, Sunnah, and has become the ijmā' of scholars and Muslims. ${ }^{2}$ Even buying and selling is not only muamalah but is a medium for activities to help others.

Islam has provided rules and a reasonably clear and firm foundation as stated by legal experts regarding the pillars, conditions, forms of buying and selling, whether allowed or not. A Muslim, both individuals, and groups in carrying out business activities, on the one hand, is given the freedom to seek maximum profit. Still, on the other hand, he is bound by beliefs and ethics, not to have absolute freedom to invest or spend his wealth. This is also in line with Fathoni's opinion that buying and selling transactions, including things that are important to its uniqueness and wisdom, are revealed in the Islamic tradition.

\footnotetext{
1 Teungku Muhammad Hasbi As-Siddieqy, Hukum-Hukum Fiqh Islam, Tinjauan Antar Mazhab (Semarang: Pustaka Rizki Putra, 2001), 328.

${ }^{2}$ Mustofa Imam, Fiqih Muamalah Kontemporer (Jakarta: Raja Grafindo Persada, 2016), 22.
} 
Buying and selling is a contract that has existed since the Prophet Muhammad and has a vital position in muamalah. ${ }^{3}$

Islamic buying and selling activities also always pay attention to various benefits and eliminate all forms of harm. Currently, buying and selling have developed quite rapidly, especially in buying and selling objects ( $m a^{\prime} q u \bar{d}$ 'alayh). Of course, buying and selling must be like each other. The rule of Islamic law, in principle, 'aqd agreement is an agreement between the parties and the legal consequences they determine. Whereas seen from muamalah fiqh, buying and selling as part of muamalah has a clear legal basis, both from the Qur'an, Sunnah, and has become the ijmá' of scholars and Muslims. Even buying and selling is fun, but it is one of the media to do activities to help others.

In practice, buying and selling must be done consistently and can provide benefits to those concerned. Buying and selling is a means of sustenance shown by Allah SWT to humans and a form of worship to meet the necessities of life inseparable from social relationships. One of the buying and selling carried out by the Jagaraga village community is the sale and purchase of game meat. However, there has never been any research related to a review of Islamic law on buying and selling game meat until now. Based on the preceding, it is necessary to conduct a preliminary study regarding a review of Islamic law on buying and selling game meat in Jagaraga Village, Sukau District, West Lampung Regency.

This research includes field research, which in essence is a way to know the specifics and reality of what is happening within the scope of buying and selling game meat that has long been going on in the community and expressed in the form of symptoms or social processes. The method used in this research is qualitative. In studying buying and selling with the concept of Islamic law, the reason is that it gives birth to an explanation that will give rise to a description of the sale and purchase of game meat. In this case, the writer observed directly the meat buying and selling mechanism carried out by the community of Jagaraga village, Sukau District, West Lampung Regency.

This research is an analytical descriptive study, which is research that aims to investigate in detail human activities and work, and the results of this study

\footnotetext{
${ }^{3}$ Nur Fathoni, 'Analisis Normatif-Filosofis Fatwa Dewan Syari'ah Nasional Majelis Ulama'Indonesia (DSN-MUI) tentang Transaksi Jual Beli pada BankSyari'ah', Al-Ahkam 25, no. 2 (2015): 140.
} 
can provide recommendations for future needs. ${ }^{4}$ This research focuses more on the problem of determining the law of buying and selling game meat related to the question of buying and selling, selling mechanisms, payment, and how to get game animals. Therefore, this study's data source is data obtained directly from respondents or the object under study. In this case, the researcher's primary data comes from the players who buy and sell game meat and who understand the transactions in the game meat buying and selling mechanism.

The population studied in this study were 150 people in the village of Jagaraga as hunters. The author tries to find as much information as possible about the systematic process of buying and selling game meat. The sample taken is 15 people. The methods used for data collection are observation and interview methods. The researchers observed the game mechanism of buying and selling wild animal meat by the Jagaraga village community. Here, the author also prepares a list of questions to be asked directly to the party conducting the sale and purchase of game meat, which will then be reviewed from Islamic law. This research's data analysis method is a qualitative method adapted to the research study, namely buying and selling game meat as seen from the Islamic law to be studied. In essence, this analysis aims to determine the 'aqad of buying and selling, the buying and selling system, and the procedures for getting game animals, whether it is according to Islam's rules. The goal can be seen from the perspective of Islamic law, which is to make scientific contributions and understand the buying and selling of meat that is hunted in Islamic law.

\section{The Concept of Buying, Selling, and Hunting}

Buy and sell in the Arabic language comes from the word (البيح), which means to sell, replace, and swap something for something else. ${ }^{5}$ Pronunciation sometimes used to understand the opposite, namely the word البيع said means selling and at the same time also means buying. ${ }^{6}$ Etymologically, buying and selling means exchanging something for something, while according

\footnotetext{
${ }^{4}$ M S Kaelan, Metode Penelitian Kualitatif Bidang Filsafat (Yogyakarta: Paradigma, 2005), 69.

5 Mahmud Yunus, Kamus Arab-Indonesia (Jakarta: Hadikarya Agung, 1997), 56.

${ }^{6}$ Muhammad Ali Hasan, Berbagai Macam Transaksi dalam Islam (Jakarta: Raja Grafindo Persada, 2003), 113.
} 
to shar', it means exchanging property for property in a certain way or contract.7 Meanwhile, buying and selling are defined as "exchange of interest" or "transfer of ownership using replacement by the permitted form." The word "exchange" or "transfer of ownership for replacement" implies the same objective that the activity of transferring rights and ownership occurs reciprocally based on mutual will and desire. The words "equal to like" or "according to the allowable form" implies that this reciprocal transaction behaves according to the permitted form "means that this mutual transaction is valid in a predetermined manner, consensual. ${ }^{8}$

According to Islamic law, they exchange goods for goods or goods for money by relinquishing property rights to one another based on mutual surrender. According to Hanafiyah scholars, buying and selling is the exchange of property for assets based on a unique or permitted manner. ${ }^{9}$ Meanwhile, according to Suhendi, the sale and purchase point is an agreement to exchange objects or goods that have a voluntary value between the two parties. One accepts the thing, and the other party gets it by the contract or terms justified by shar' and agreed upon. ${ }^{10}$

As for buying and selling in Islam, it is based on the following arguments.

a. Al-Baqarah (2): 275

$$
\text { ......... }
$$

Meaning: "... and Allah has legalized buying and selling and forbidden usury ..."

The purpose of the above verse is that it can be a part of their words (usury eaters) and a rebuttal for themselves. That is, they say that (innama al-mathal al-riba $)$ when in fact they know that there is a difference between buying and

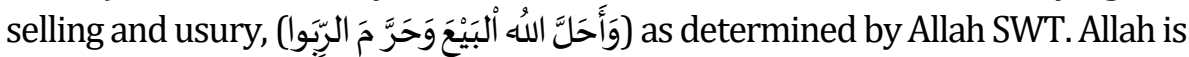
all-knowing, all-wise, no one can refuse His provisions, and it is they who will be held accountable. Allah is omniscient about what problems are beneficial to His servants so that He will allow them. ${ }^{11}$

\footnotetext{
7 Moh Rifa'i, Fiqih Islam (Jakarta: Bulan Bintang, 1992), 402.

${ }^{8}$ M. Amir Syarifudin, Garis Besar Fiqih (Jakarta: Kencana, 2003), 193.

${ }_{9}^{9}$ Syafe'i Rachmad, Fiqih Muamalah (Bandung: Pustaka Setia, 2001), 74.

${ }^{10}$ Hendi Suhendi, Fiqih Muamalah (Jakarta: Raja Grafindo Persada, 2001), 69.

11 Muhammad Nasīb Al-Rifā̄î, Ringkasan Tafsir Ibnu Katsir, ed. Syihabuddin (Jakarta: Gema Insani Press, 1999), 54.
} 
The verse explains that Allah allows people to buy and sell transactions to meet their daily needs. But of course, the sale and purchase transaction must be following the corridors or provisions that Allah has set.

b. The hadīth of the Prophet narrated by Ahmad which means "from Rāfi' Ibn Khudayj he said: someone asked Rasūlullāh; "what is the best effort, O Messenger of Allah." He answered "someone who worked on his own business and bought and sold well" (justified by Islamic law)."12 The hadīth narrated by Ibn Mājah which means "from Sa'īd alKhudharī he said; Rasūlullāh said; "actually buying and selling must be based on consensual."13

c. The basis of $i j m \bar{a}^{\prime}$, that buying and selling and its diligence has been valid (justified) since the Prophet's time to this day. ${ }^{14}$ Willingness is the key to buying and selling transactions because, without mutual willingness, buying, and selling are illegal. All forms of muamalah can be done unless there is an argument that prohibits it. The fundamental law of everything is permissible until there is evidence that changes it. 15

\section{Pillars and Terms of Sale and Purchase}

Buy and sell by Islamic law must fulfill the pillars and requirements of buying and selling. Simultaneously, harmony and conditions must be fulfilled so that the sale and purchase are considered valid because buying and selling is a contract. The terms and conditions must be fulfilled. ${ }^{16}$ There are three pillars of buying and selling: the agreement, the people who act (the seller and the buyer), and the ma'qūd 'alayh (the contract's object). ${ }^{17}$ 'Aqd comes from Arabic, which means a recorded agreement or contract. ${ }^{18}$ uying and

\footnotetext{
12 Siti Mujiatun, 'Jual Beli dalam Perspektif Islam: Salam dan Istisna", JRAB: Jurnal Riset Akuntansi \& Bisnis 13, no. 2 (2014): 205.

13 Mujiatun, 205.

14 Sayyid Sabiq, Fiqih Sunnah, Jilid IV (Bandung: al-Ma'arif, 1987), 48.

${ }^{15}$ Abdul Mujib, Kaidah-Kaidah Ilmu Fiqh (Jakarta: Kalam Mulia, 2010), 25.

16 Syaifullah Syaifullah, 'Etika Jual Beli dalam Islam', HUNAFA: Jurnal Studia Islamika 11, no. 2 (2014): 371-87.

17 Siswandi, 'Jual Beli dalam Perspektif Islam', Jurnal Ummul Qura 11, no. 2 (2000): 62-63.

18 Muhammad Yunus, Fahmi Fatwa Rosyadi Satria Hamdani, and Gusti Khairina Shofia, 'Tinjauan Fikih Muamalah Terhadap Akad Jual Beli dalam Transaksi Online pada Aplikasi Go-Food', Amwaluna: Jurnal Ekonomi dan Keuangan Syariah 2, No. 1 (2018): 135-46.
} 
selling are not valid until the ïjab and qabūl are done because the consent of the qabūl shows willingness (pleasure). The consent of the qabūl is done verbally, but if this is not possible, for example, mute or something else, the consent of the qabūl is permissible in the correspondence which contains the meaning of consent and qabül. ${ }^{19}$

The requirements for the seller and the buyer's validity are; baligh (adult), Muslim, some goods are traded (ma'qūd 'alayh), not redundant, and there is no coercion from other parties. ${ }^{20}$ The requirements for the validity of goods being traded are: First, it is pure and not unclean, such as dogs, pigs, and animal waste, except in an emergency, and there is a principle of benefit. Second, there are no requirements, such as "if my father dies, I will sell this motorbike." Third, not limited by time. Fourth, goods can be sent after there is a contract agreement. Fifth, the goods being traded are their property. The sale and purchase agreement will not be valid if the goods resulting from theft or entrusted goods have no permission. Sixth, the goods being traded can be known (seen). Seventh, the goods being exchanged must be known for their quality, weight, size, and size so as not to raise doubts. ${ }^{21}$

\section{Basic Laws of Hunting}

The consensus of scholars states that the law of origin of hunting is permissible and the direction of the head of hunting is halal. Meanwhile, Mālik confirmed animal hunting if the goal was an exaggeration. 'Abd alRahmmān Juzairy prohibits hunting animals if it causes damage to agriculture, chaos to housing, and the purpose of hunting is fun and play. ${ }^{22}$

All efforts made inevitably involve other people, either directly or indirectly. Likewise, in meeting their needs, every effort is made to meet their needs. For example, by trading, farming, labor, or other things such as hunting. Al-Mā'idah (5) Verse 4 states:

\footnotetext{
${ }^{19}$ Siswandi, 'Jual Beli dalam Perspektif Islam', 63. 79.

20 Wati Susiawati, 'Jual Beli dalam Konteks Kekinian', Jurnal Ekonomi Islam 8, no. 02 (2017): 178-

${ }^{21}$ Susiawati, 179.

22 Fachrurazi dan Yusuf, 'Fatwa Satwa: Kajian Fiqh dan Hukum Positif tentang Perburuan Satwa', Al-Maslahah:Jurnal Ilmu Syariah 13, no. 1 (2017): 109-30.
} 
Meaning: "... Say:" It is legal for you who are good and (the game captured) by the wild beast which you have taught by training it to hunt; you teach it according to what Allah has taught you ......"

Based on this information, it is clear that hunting is allowed. It's just that the question arises about how the hunters carried out the hunt. In this case, Islamic law has regulated hunting procedures with the following conditions:

a. Muslims or "people of the book" do so with the intention of hunting, not just for fun. ${ }^{23}$

b. Do not hunt while on ihram.

c. Read basmalah when going to do it.

d. If using a hunting animal, such as a hunting dog, then say the name Allah when releasing it.

e. Using sharp tools so as not to torture prey. ${ }^{24}$

Meanwhile, the hunters in Jagaraga did group hunting. They brought hunting tools in the form of spears, and some were carrying air rifles. They also use hunting animals to catch their prey, namely hunting dogs, which they have trained to hunt animals.

\section{Protection and Preservation of Ecosystems in Laws and Fatwas}

Animals are one of the priceless natural resources. They need to be preserved to not become extinct due to biological factors or human activity, such as hunting. According to Article 1 Paragraph 5 of Law no. 05 of 1990 concerning Conservation of Living Natural Resources and their Ecosystems, animals are all kinds of natural animal resources that live on land, water, and/or air. Whereas what is meant by animals, Article 1 Paragraph 7 defines it as all animals that live on land, in water, and/or in the air that still has wild characteristics, either those that live freely or are cared for by humans. Besides, wild animals can be defined as animals that live on land or in water that still have excellent characteristics. ${ }^{25}$

\footnotetext{
${ }^{23}$ Sabiq, Fiqih Sunnah.

24 Yūsūf Al-Qarḍawī, Al-Halāl wa al-Ḥarām fi al-Islām (Beirut: Manshūrāt al-Maktabah al-Islām, 1969), 38.

25 Law of the Republic of Indonesia No. 5 of 1990 concerning Conservation of Living Natural Resources and Their Ecosystems
} 
The prohibition on the improper treatment of protected animals is stipulated in Article 21 paragraph (2) of Law no. 5 of 1990.

a. Capturing, injuring, killing, raising, possessing, maintaining, transporting, and trading protected animals when they die;

b. Storing, owning, maintaining, transporting, and trading dead animals;

c. Moving protected animals from one place in Indonesia to another location inside or outside Indonesia;

d. Breeding, raising, or possessing skins, bodies, or articles made of animal parts or moving them from one place in Indonesia to another inside or outside Indonesia;

e. Taking, destroying, destroying, trading, keeping, or possessing eggs and/or protected animal nests. ${ }^{26}$

The criminal sanction for a person who deliberately violates the provisions referred to in Article 21 Paragraph (2) is a maximum imprisonment of 5 (five) years and a maximum fine of Rp 100,000,000.00 (one hundred million rupiahs) (Article 40 Paragraph (2) ) Law 5/1990). There are exceptions to the capture of protected animals, which can only be carried out for research, science, and/or rescue of the plant and animal species concerned. Besides, exceptions from the prohibition of capturing protected animals can also be made if for any reason protected animals endanger human life. The harm here does not mean that it does not only threaten human life but also causes disturbance or anxiety towards the tranquility of human life.

Meanwhile, the Council of Indonesia Ulama (MUI) stated as follows. First: General Provisions. In this fatwa, what is meant by endangered species are all kinds of natural animal resources that live on land, water, and/or in the air, protected or not, whether living in the wild or in captivity, having a small population and the number in nature has decreased sharply. If there is no rescue effort, it will become extinct.

Second: legal provisions

1. Every living thing has the right to take on its life and be utilized to benefit humanity

${ }^{26}$ Law of the Republic of Indonesia No. 5 of 1990 concerning Conservation of Living Natural Resources and Their Ecosystems 
2. Treating endangered species well (ihsān) by protecting and preserving them to ensure their survival is obligatory

3. Protection and preservation of endangered species as referred to in number 2, among others by way of:

a. Ensure basic needs, such as food, shelter, and reproductive needs;

b. Not giving burdens that are beyond their limits

c. Do not mix with other animals that endanger it

d. Maintain habitat integrity

e. Prevent poaching and illegal trade

f. Prevent conflicts with humans;

g. Maintain animal welfare (animal welfare).

4. Rare animals may be used for benefit by the Sharia provisions and the requirements of statutory regulations.

5. Utilization of endangered species as referred to in number 4, among others, by road;
a. Maintain ecosystem balance;
b. Use it for the benefit of ecotourism, education, and research
c. Use it to maintain environmental safety;
d. Cultivate for benefit by statutory regulations.

6. Killing, hurting, torturing, hunting, and/or taking action that threatens the extinction of endangered animals is haram unless there is a shar'ī reason, such as protecting and saving human lives

7. Illegal hunting and/or trading of endangered species is haram. ${ }^{27}$

\section{The Practice of Buying and Selling Game Meat \\ Types of Animals Hunted in Jagaraga Village}

The hunters go on a hunt to sell their prey. This activity disturbs the balance of the ecosystem. Moreover, if there is no conservation effort, animal breeding will be disrupted, and protected animals' extinction is a significant loss. Simultaneously, the types of animals that are often hunted in Jagaraga

\footnotetext{
27 Komisi Fatwa Majelis Ulama Indonesia, 'Fatwa No. 4 Tahun 2014 Tentang Pelestarian Satwa Langka Untuk Menjaga Keseimbangan Ekosistem’, 2014.
} 
Village include deer, deer, pangolins, mouse deer, hedgehogs, ivory hornbills, crows, and pigs. The list of animals is protected by the state, except for pigs.

Hunters in Jagaraga admit that they are still hunting several protected animals. The writer found this statement when conducting interviews with them..$^{28}$ At first, they hunted animals considered pests, such as pigs, monkeys, and squirrels. But when they encounter deer, pangolins, hedgehogs, mouse deer, and so on, they will hunt them.

The hunting is carried out every Friday. After Friday prayers, they headed for the designated hunting location. Often, they go hunting at the foot of Mount Seminung. The place is the location because it is close to residents' land, which was damaged by animals.

Regarding the results of hunting, they differentiated it into two categories, halal animals and animals that are forbidden to consume. For unclean animals, they usually give it to the hunting dogs they bring. However, if there is an order or someone buys it, they will sell it. As for halal animals, they will divide the meat evenly or sell it, and they will share the money from the sale evenly.

They hunt protected animals because of their lack of understanding about the prohibition of hunting protected species. This prohibition is regulated by Law no. 05 of 1990 Article 21 Paragraph (2). The illegal hunting was exacerbated by the absence of supervision from the authorities. As a result, illegal hunting continues, and the game products are traded freely and illegally. If this is allowed, it can threaten animals' existence and disturb the balance of the ecosystem in nature.

\section{Implementation of Buying and Selling Game Meat in Jagaraga Village}

The sale and purchase of game meat are carried out by the villagers of Jagaraga when the hunters have returned from the hunting grounds. They sell it to the villagers of Jagaraga by visiting the buyer's residence. The meat

28 The author conducted direct interviews with hunters in Jagaraga. They are Mang Rohim, Ardiansyah, Sodikul Asrori, Veri Irawan, Rizki Bahrul Alamsyah, Agung Permana, Ikbal Mahesa, Ahmaril Fariqi, Muhammad Nur Kholis, Mang David, Novrian, Nizomi, Muhammad Mahmud, Apriyansah, and Erpan Sairi. 
sold is in the form of venison, mouse deer, and forest deer. If it is in the form of wild boar, it is used as pet dog food, but some are sold to non-Muslim people. Based on Mang Rohim's statement, they sold game meat to residents or offered it on their way home. Meat sold to residents is animal meat that is halal in Islam.

Meanwhile, the pigs from hunting are fed to hunting dogs and have not been slaughtered. However, when someone wants to buy, we also sell it to buyers from outside the village. The sale and purchase of game meat fulfill the legal requirements of buying and selling. Still, because the sale and purchase object are an animal protected by the state and prohibited from doing damage, the sale is considered canceled, and if it continues, the law will turn into haram.

\section{The View of Islamic Law About Buying and Selling Game Meat}

Islamic law, in terms of buying and selling, provides terms and conditions. The main principle in muamalah activities is that everything can be done, including buying and selling activities. This is as mentioned in al-Nisā' Verse 29. Meaning: "... do not eat the wealth of your neighbor in a way that is vanity (not true), except in trade which is consensual between you ..."

This verse explains that buying and selling are permissible if it is done by the rules justified by Islamic law, such as there is no element of usury. If it is not following Islamic law, trading is prohibited. ${ }^{29}$ Thus, the buying and selling process is not merely a transaction for the transfer of goods from a particular party, but also must be considered regarding the terms and conditions. These factors determine the validity of the sale and purchase.

As already explained, the pillars of buying and selling are the existence of sellers and buyers, the presence of goods, and sighat (al-ïjab wa al qabūl). Another requirement is the purity and usefulness of goods. The seller is the owner of the item himself or a person who is permitted by the owner.

If the perpetrators follow the rules correctly, then unauthorized buying and selling can be avoided. Regarding the buying and selling of game meat in the field, game meat that is sold is protected by the state and prohibited in Islam as

${ }^{29}$ Sayyid Quțb, Tafsìr fi Zịilāl al-Qur'ān (Jakarta: Gema Insani Press, 2001), 342. 
a form of ecosystem protection in nature (hifz al-bi'ah). However, it has been done with the agreement of the parties.

In this regard, the Qur'an pays close attention to the importance of preserving animals and maintaining the balance of the ecosystem on earth. The verses in the Qur'an emphasize the importance of the role of humans as caliphs on earth, one of which is to save and preserve animals (including endangered animals) so they do not become extinct (al-Baqarah [2]: 30). This shows that protecting and preserving animals is a necessity.

Apart from the commandment to conserve nature, the Koran also prohibits humans from destroying nature, including killing endangered animals (al-A'raf [206]: 56). At the same time, the Qur'an also commands humans to do good (ihsān) to all creatures, including animals (al-An'ām [6]: 38)

Qawā'id fiqhiyyah concerning muamalah state:

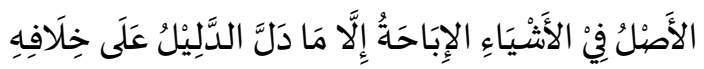

Meaning: "In principle, everything (outside of worship) is permissible unless there are arguments that show otherwise." ${ }^{30}$

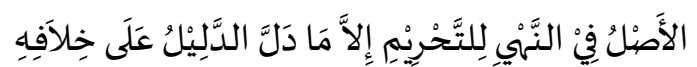

Meaning: "In principle, the form of prohibition shows the status of haram, unless there is evidence that shows otherwise". ${ }^{31}$

Based on the description above, it can be concluded that buying and selling game meat is allowed unless someone prohibits it, such as a ban on hunting endangered animals. The state, in this case, has banned the hunting and killing of protected animals. Also, Islam does not only invite humankind to believe and worship, but also to do good (ihsānn) to fellow humans and nature.

The Qur'an also explains the prohibition of destroying ecosystems in nature by selling protected, traded, or endangered animals. The Prophet's Hadith emphasizes this to love animals and not to do wrong to fellow beings. The opinion of the scholars also emphasizes that the status of haram refers to a form of prohibition. Meanwhile, through Fatwa No. 4 of 2014 concerning Endangered Animal Conservation to Protect Ecosystems, MUI provides a fatwa prohibiting

${ }^{30}$ Abdul Mujdib, Kaidah-Kaidah Ilmu Fiqih (Al-Qowa'idul Fiqhiyyah) (Jakarta: Kalam Mulia, 2016), 25. Komisi Fatwa Majelis Ulama Indonesia, 'Fatwa Nomor 22 Tahun 2011 Tentang Pertambangan Ramah Lingkungan', 2011.

${ }^{31}$ Abdul Mujdib, Kaidah-Kaidah Ilmu Fiqih (Al-Qowa'idul Fiqhiyyah), 25 
the sale and purchase of game meat, which is forbidden by the state. Although the terms and conditions of sale and investment have been met, the sale and purchase ( $m a a^{\prime} q u \bar{d}$ 'alayh) is prohibited by the government and religion.

\section{Conclusion}

Hunters carry out the sale and purchase of game meat in Jagaraga without government authorities' supervision to impact the extinction of animals if done continuously. It is necessary to raise public awareness by providing education about the prohibition of hunting animals, especially animals that have been protected by the state through Law no. 05 of 1990 concerning the Conservation of Natural Resources and Their Ecosystems. Through verses, hadiths, opinions of scholars, and fatwas, Islamic law also explicitly prohibits these acts. Prohibition of hunting activities for protected animals, thus the meat of these animals is also banned from being traded.[a]

\section{BIBLIOGRAPHY}

Ali Hasan, Muhammad. Berbagai Macam Transaksi dalam Islam. Jakarta: Raja Grafindo Persada, 2003.

As-Siddieqy, Teungku Muhammad Hasbi. Hukum-Hukum Fiqh Islam, Tinjauan Antar Mazhab. Semarang: Pustaka Rizki Putra, 2001.

Fachrurazi dan Yusuf. 'Fatwa Satwa: Kajian Fiqh dan Hukum Positif tentang Perburuan Satwa'. Al-Maslahah: Jurnal Ilmu Syariah 13, no. 1 (2017): 109-30.

Fathoni, Nur. 'Analisis Normatif-Filosofis Fatwa Dewan Syari'ah Nasional Majelis Ulama'Indonesia (DSN-MUI) Tentang Transaksi Jual Beli pada Bank Syari'ah'. Al-Ahkam 25, no. 2 (2015): 139-60.

Imam, Mustofa. Fiqih Muamalah Kontemporer. Jakarta: Raja Grafindo Persada, 2016.

Kaelan, M S. Metode Penelitian KualitatifBidang Filsafat. Yogyakarta: Paradigma, 2005.

Komisi Fatwa Majelis Ulama Indonesia. 'Fatwa No. 4 Tahun 2014 Tentang Pelestarian Satwa Langka Untuk Menjaga Keseimbangan Ekosistem', 2014. 
- ——. 'Fatwa Nomor 22 Tahun 2011 Tentang Pertambangan Ramah Lingkungan', 2011.

Mujiatun, Siti. 'Jual Beli dalam Perspektif Islam: Salam dan Istisna”. JRAB: Jurnal Riset Akuntansi \& Bisnis 13, no. 2 (2014).

Mudjib, Abdul. Kaidah-Kaidah Ilmu Fiqh. Jakarta: Kalam Mulia, 2010.

Al-Qarḍawī, Yūsūf. Al-Halāl wa al-Harām fi al-Islām. Beirut: Manshūrāt alMaktabah al-Islām, 1969.

Quṭb, Sayyid. Tafsïr fi Zilā̄l al-Qur'ān. Jakarta: Gema Insani Press, 2001.

Rachmad, Syafe'i. Fiqih Muamalah. Bandung: Pustaka Setia, 2001.

Rifa'i, Moh. Fiqih Islam. Jakarta: Bulan Bintang, 1992.

Al-Rifāî, Muḥammad Nasīb. Ringkasan Tafsir Ibnu Katsir. Edited by Syihabuddin. Jakarta: Gema Insani Press, 1999.

Sabiq, Sayyid. Fiqih Sunnah. Jilid IV. Bandung: al-Ma’arif, 1987.

Siswandi. 'Jual Beli dalam Perspektif Islam'.Jurnal Ummul Qura 11, no. 2 (2000): 371-87.

Suhendi, Hendi. Fiqih Muamalah. Jakarta: Raja Grafindo Persada, 2001.

Susiawati, Wati. 'Jual Beli dalam Konteks Kekinian'. Jurnal Ekonomi Islam 8, no. 02 (2017): 171-84.

Syaifullah, Syaifullah. 'Etika Jual Beli dalam Islam'. HUNAFA: Jurnal Studia Islamika 11, no. 2 (2014): 371-87.

Syarifudin, M. Amir. Garis Besar Fiqih. Jakarta: Kencana, 2003.

Yunus, Mahmud. Kamus Arab-Indonesia. Jakarta: Hadikarya Agung, 1997.

Yunus, Muhammad, Fahmi Fatwa Rosyadi Satria Hamdani, and Gusti Khairina Shofia. 'Tinjauan Fikih Muamalah Terhadap Akad Jual Beli dalam Transaksi Online pada Aplikasi Go-Food'. Amwaluna: Jurnal Ekonomi dan Keuangan Syariah 2, no. 1 (2018): 135-46. 
